Citation: Kıran, F., \& Ekşili, N., \& Çetinkaya Bozkurt, Ö., Franchise Alan İşletmelerin Partner Seçimi: Gida Sektöründe Nitel Bir Araştırma, BMIJ, (2020), 8(4): 296-328, doi: http://dx.doi.org/10.15295/bmij.v8i4.1717

\title{
FRANCHISE ALAN İŞLETMELERİN PARTNER SEÇİMİ: GIDA SEKTÖRÜNDE NITTEL BİR ARAŞTIRMA ${ }^{1}$
}

Funda KIRAN 2

Nisa EKŞİLİ 3

Özlem ÇETINNKAYA BOZKURT 4
Received Date (Başvuru Tarihi):

$17 / 02 / 2020$

Accepted Date (Kabul Tarihi):

$23 / 09 / 2020$

Published Date (Yayın Tarihi):

$10 / 12 / 2020$
$\ddot{O Z Z}$

\section{Anahtar Kelimeler:}

Partner Seçimi,

Franchising,

Franchisee,

Franchisor

JEL Kodları:

M10,

G34,

M13

Bu çalışmanın amacı gıda sektöründe franchiseelerin franchisorı seçme nedenlerini ortaya koymak ve bazı değişkenlerle karşılaştırma yapmaktır. Bu nedenle derinlemesine bilgi almak amacıyla yarı-yapılandırılmış görüşme tekniŏinin kullanıldığı araştırmada, literatür taraması sonucunda oluşturulan soru formu kullanılmıştır. Araştırmanın örneklemini Antalya ve Burdur illerinde gıda sektöründe faaliyet gösteren kolayda ve kartopu örneklem yöntemiyle ulaşılmış toplam 16 franchisee oluşturmaktadır. Yapılan görüşmeler MAXQDA 18.0 paket programı kullanılarak analiz edilmiştir. Analizler sonucunda franchise alan işletmelerin partner seçiminde en fazla dikkat ettiŏi faktörün konsept - ürün çeşitliliği olduğu görülmüştür. Ardından sırasılala ikili ilişkiler, marka, firma potansiyeli, profesyonellik, ürün ve hizmet standardı, yatırım şartlarının uygunluğu, kârlılık oranı ve lojistik desteğin dikkat edilen unsurlar olduğu tespit edilmiştir. Girişimciler partnerleriyle yaptıkları görüşmelerde sırasıyla finansman, franchisee kimliği, sözleşmenin tek taraflı olmasi, yer seçimi ve franchisee olarak faaliyete başlama süresinin uzun olması gibi problemlerle karşılaşmışlardır. Franchiseeler anlaşma sonrasında sırasıyla yanıltıcı/yetersiz danışmanlık, sözleşme şartlarına hâkim olamamak, tedarik ve franchise veren işletmenin yeterli tecrübesinin olmamasından kaynaklı zorluklarla karşılaştıkların ifade etmişlerdir. Sonuç olarak işletmelerin yeterli oranda partner seçimi kriterlerini dikkate almadıkları ve zorluklar yaşadıklan belirlenmiştir.

\begin{tabular}{|c|c|c|c|}
\hline Keywords: & Partner Selection & Franchising & Franchisee \\
\hline JEL Codes: & M10 & G34 & M13 \\
\hline
\end{tabular}

\footnotetext{
${ }^{1}$ Bu çalışma 23-25 Eylül 2020 tarihlerinde Erciyes Üniversitesi'nde düzenlenen 19. Uluslararası İşletmecilik Kongresi'nde sunulan bildirinin geliştirilmiş ve genişletilmiş halidir.

${ }^{2}$ Arş. Gör., Burdur Mehmet Akif Ersoy Üniversitesi, fkiran@mehmetakif.edu.tr,

${ }^{3}$ Dr. Öğr. Üyesi, Akdeniz Üniversitesi, nisaeksili@akdeniz.edu.tr,

https://orcid.org/0000-0002-6456-2497

${ }^{4}$ Prof. Dr., Burdur Mehmet Akif Ersoy Üniversitesi, ozlemcetinkaya@mehmetakif.edu tr https://orcid.org/0000-0002-6218-2570
} 


\section{EXTENDED ABSTRACT}

\section{FRANCHISEES' PARTNER SELECTION PROCESS: A QUALITATIVE RESEARCH IN FOOD SECTOR}

\section{LITERATURE}

\subsection{RESEARCH SUBJECT}

In addition to the increasing competition with the effect of globalisation, the high cost and risk of developing new products and entering new markets are among the fundamental reasons that motivate companies to work in partnership (Hitt, Dacin, Levitas, Arregle and Borza, 2000; Tuunanen and Hyrsky, 2001; Guilloux, Gauzente, Kalika and Dubost, 2004). Franchising has also emerged as a form of a strategic partnership that expands faster and more robust than other types of partnerships in international service industries (Doherty and Alexander, 2004; Alon, 2006). In this strategic partnership, one of the essential management functions is partner selection. These selection processes and their consequences have potentially far-reaching effects on the customer's perception of the business, organisational cooperation and financial performance of a firm. The importance of partner selection becomes apparent, especially when considering that the parties have to fulfil their obligations for a long time by sticking to the contract and that the parties generally make significant financial investments in their business relations (Clarkin and Swavely, 2006). In the literature, studies conducted to investigate the reasons for partner selection in franchising (Clarkin and Swavely, 2006; Altinay, Brookes, Madanoglu and Aktas, 2014; Brookes and Altinay, 2011; Doherty, 2009), examine selection process and reasons of results from two perspectives in terms of franchisor and franchisee. This research has been designed based on research question about which factors do franchisees operating in the food sector in Antalya and Burdur provinces take into account in the selection of the franchisor.

\subsection{RESEARCH PURPOSE AND IMPORTANCE}

In this research, determining the factors that franchisees operating in the food sector in Antalya and Burdur provinces take into account in the selection of the franchisor is aimed. Also, these factors were compared with demographic variables, difficulties experienced during the franchising agreement and difficulties experienced after the franchising agreement.

The findings may shed light on the franchisees' factors that should be considered in the selection process. Also, it is believed that franchisees can more clearly identify the priority areas they need to develop themselves in order to find better partners.

\subsection{CONTRIBUTION of the ARTICLE to the LITERATURE}

This study will try to contribute to the literature by providing information about the details of partner selection, which is one of the essential pillars of the franchising system in Burdur and Antalya.

\section{DESIGN AND METHOD}

\subsection{RESEARCH TYPE}

This study is a research article, and qualitative research design was adopted.

\subsection{RESEARCH PROBLEMS}

In this study, the authors tried to find out the criteria which franchisees take into account while selecting partners.

\subsection{DATA COLLECTION METHOD}

The data was collected from franchisees operating in the food sector in Antalya and Burdur provinces. The widespread use of the franchise system in the food industry in Turkey (Alkan, 2015) has 
been effective in choosing this sector. In this study, the interview method was used. Semi-structured interview technique was selected to get in-depth information in interviews with franchisees. Before starting the interviews, the relevant literature was scanned, and some of the questions that can be included in the research have been determined. Additional questions were also directed during the interview. The method of convenience and snowball sampling was used in creating the sampling. After collecting data from 16 franchisees, the answers began to repeat; for this reason, the interviews were concluded.

\subsection{QUANTITATIVE / QUALITATIVE ANALYSIS}

In the study, the content analysis, which is one of the qualitative analysis, was performed.

\section{FINDINGS AND DISCUSSION}

\subsection{FINDINGS as a RESULT of ANALYSIS}

It has been determined that concept - product diversity, bilateral relations, brand, company potential, professionalism, product and service standard, compliance of investment conditions, profitability ratio and logistic support are the factors that franchisees pay the most attention.

Examining whether there is a differentiation in the selection of franchisees in terms of businesses specialised in beverage and food, it is seen that the enterprises in the food sector focus more on professionalism, compliance of investment conditions and product - service standards. On the other hand, in the beverage sector, the concept is preferred out.

When the experience of franchisees was examined, it is seen that franchisees are generally inexperienced in the sector and the franchising system. Results show that experienced franchisees give importance to the concept - product variety and inexperienced ones rely more on bilateral relations.

According to results which are about the comparison of scale, it was determined that the number of enterprises that chose a national brand was higher and these enterprises pay attention to bilateral relations and compliance of investment conditions. On the other hand, findings show that the selection process of businesses who want to work with international businesses is more professionally.

Criteria of franchisees with different geographical conditions do not differ from each other.

The finding of education level shows that the number of franchisees who have a bachelor's or higher degree is more-individuals with a high level of education select franchisors that have a pleasant concept and high product variety.

According to the findings, more than half of the entrepreneurs (11 businesses) expressed their satisfaction. Besides, it is seen that most of the enterprises (10 enterprises) are active when franchisees were examined after one year later from the interview made. In the study, it was determined that almost all of the unsatisfied businesses take bilateral relations into consideration. On the other hand, it is observed that businesses that can continue their activities attach relatively importance to bilateral relations. This situation presents a complex outlook.

Whether the franchisees had difficulties during the agreement is examined, and the results show that entrepreneurs encountered problems such as financing, franchisee identity, unilaterality of the contract, location selection and long start-up period as a franchisee.

The problems faced by franchisees after starting the franchising system are misleading/inadequate consultancy, difficulties arising from not being able to dominate the contract terms, supply difficulties and difficulties arising from the lack of sufficient experience of the franchisor. On the other hand, four businesses stated that they had no difficulties after starting their businesses. It has been observed that these enterprises do not take into account the strong growth potential and the suitability of investment conditions.

\subsection{DISCUSSING the FINDINGS with the LITERATURE}

When the studies investigating the essential factors are examined, it is seen that the brand is the most emphasised factor (Altinay, Brookes, and Aktas, 2013). Also, some researches (Seven, 2007; Arman, Ekşili, Kıran, and Çetinkaya Bozkurt, 2019) determined that branding is the most significant driving force for companies in the food sector to prefer franchising. The focus of the brand makes the results 
similar to literature. However, even if the brand is placed near the top in the results of the study, the concept - product diversity and bilateral relations have surpassed the brand in the sample where the research was conducted. According to literature; the franchisees, who examine the product from different angles, state that the reasons of selecting product are their quality, cleanness, healthiness and safety of product especially in the food sector or their potential to take a market opportunity such as entering the shopping mall (Altinay, Brookes, and Aktas, 2013). Product diversity and product service standard stand out in the selection of the franchisor in this study, as in other studies.

According to research, there is differentiation in the partner selection process between the food and beverage sector. It is thought that the reason for this difference is the sample. In the sample, businesses in the beverage sector are generally coffee shops. While coffee shops evoke sociality, pleasure and sharing, they have changed to become places where different types of coffee are served in different tastes, various appearances and alternative food in addition to drinks are served besides coffee. (Akarçay, 2012 s. One hundred eighty-six cited from Aşık, 2017). Aşık (2017) stated that the most critical factors in the choice of brand in the coffee shops are taste and presentation, price, service quality and service speed, the wide variety of coffee and the decoration of the shop, respectively.

According to the results, the number of experienced franchisees is less than inexperienced ones. The result is expected. Individuals who want to start their own business with their savings and do not have the skills, confidence or experience, are more advantageous in the franchising system than starting a new business (Aslanoğlu, 2007: 81). Individuals can reach a level where they can produce and sell goods and services in an area previously unknown to them (Tuncay, 1992: 51 as cited in Kurt and Korkmazyürek, 2019: 31). For that reason, inexperienced businesses will be more inclined to engage with the franchisor than experienced businesses. When the subject is examined in terms of franchisors perspective, the literature is contradictory. Clarkin and Swavely (2006) mentioned working with inexperienced franchisees' advantages and disadvantages. Also, Jambulingham and Nevin (1999) accept as disadvantages. According to the results, inexperienced businesses rely more on bilateral relations than experienced ones. It is thought that the difference in selection proses is an expected result. Businesses that do not have any experience cannot make a task-oriented choice; for that reason, they make partner-oriented choices.

It is argued that different social factors in different regions, habits, rules and norms in that region may affect the companies and that economic activities will be shaped by this social structure (Simmie, 2001 as cited in Albayrak and Erkut, 2010). In this direction, two different provinces were compared, and contrary to expectations, no difference was observed.

The result of the number of high education level is similar to literature (Alkan, 2015; Seven, 2007; Kurt and Korkmazyürek, 2019).

According to results, the difficulties experienced by the franchisees during the signing of the contract are different from the literature. Brookes and Altinay (2011) stated that after the starts of the negotiations, criteria related to the partner like the compatibility of the partners, the similarities between the parties' definitions of risk and value, visions, organisational cultures and goals rather than the characteristics of the franchising business are dominant. However, the results have related both partner and characteristics of the franchising.

The most common problem experienced after businesses started franchising which is misleading/inadequate consultancy is critical to the franchisee because the lack of continuous support to the partner by the franchisor is one of the common mistakes that fail the franchising system (Seven, 2007). The difficulties arising from not being able to master the terms of the contract which is the other problem is thought the result of the inexperience of the entrepreneurs or their lack of legal support. Entrepreneurs do not realise the conditions which are in favour of the franchisor, and they do not consult lawyers, or if they did, they do not find it useful (Abdullaev, 2011).

Insufficient research can cause difficulties afterwards as well as during franchise negotiations. It is thought that the supply difficulties and the lack of experience of the franchisor company are the reason for lack of research. 


\section{CONCLUSION, RECOMMENDATION AND LIMITATIONS}

\subsection{RESULTS of the ARTICLE}

The result of the article is a concept - product diversity, bilateral relations, brand, company potential, professionalism, product and service standard, compliance of investment conditions, profitability ratio and logistic support are the factors that franchisees pay the most attention. When the comparison of the other variables, it is thought that the examined factors are not enough to start this relationship.

\subsection{SUGGESTIONS BASED on RESULTS}

In the franchisor selection process, franchisees should take into account factors which are mentioned in the literature, be rigorous, intensify their research, and if necessary, seek legal support. Besides, subsequent studies may make this research dimensional while repeating interviews and analyses at certain time intervals. Also examining the subject from the perspective of the franchisor will add depth to the subject. Also, it is suggested that different regions and provinces should be included in the scope of the research in future studies.

\subsection{LIMITATIONS of the ARTICLE}

Conducting the research in only two provinces and being cross-sectional constitute are the most significant limitations of the study. 


\section{GİRIŞ}

Küreselleşmenin etkisiyle artan rekabetin yanında yeni ürünler geliştirmenin ve yeni pazarlara girmenin yüksek maliyeti ve riski, firmaları ortaklık içinde çalışmaya iten önemli sebeplerdendir (Hitt, Dacin, Levitas, Arregle ve Borza, 2000; Tuunanen ve Hyrsky, 2001; Guilloux, Gauzente, Kalika ve Dubost, 2004). Bu nedenle, şirketler aras1 ortaklıklarda artış görülmektedir. Franchising de uluslararası hizmet endüstrilerindeki diğer ortaklık türlerinden daha hılı ve daha güçlü bir şekilde genişleyen stratejik ortaklık biçimi olarak ortaya çıkmıştır (Doherty ve Alexander, 2004; Alon, 2006). İşletmeler rekabetçi hale gelebilmek ve başarılı büyüme stratejileri geliştirmek için finansal sermaye, insan sermayesi, yönetsel yetenek veya yerel pazar bilgisi gibi kaynaklara ihtiyaç duymaktadırlar (Norton, 1988; Minkler, 1990). Franchisingin, özellikle hizmet kuruluşları için gerekli olan bu kaynakları (sermaye, emek, yönetsel yetenek ve pazarlama gücü gibi) sağlıyor olması öncelikle gıda sektöründe olmak üzere konaklama, temizlik, perakendecilik gibi birçok alanda popüler hale gelmesini sağlamıştır (Brookes ve Roper, 2012; Cho, 2004; Mason ve Duquette, 2008; Clarkin ve Swavely, 2006). Franchise Direct tarafından yapılan son araştırmalar, en büyük 100 küresel franchise'ların yüzde 39'unun yiyecek içecek işletmeleri olduğunu göstermektedir (Franchise Direct, 2020). Görüldüğü üzere günümüzde stratejik ortaklık faaliyetleri, özellikle yiyecek içecek restoran zincirleri ile hızla büyüyen bir gelişme göstermektedir. Mc Donalds, Burger King, Kentucky Fried Chicken ve Pizza Hut gibi hızlı servisi temel alan şirketler, yiyecek içecek sektörü gelişiminde öncüdür ve bu şirketlerin egemenliği devam etmektedir. Fast food restoranlarında iş dünyasında son otuz yılda ve Türkiye'de son on beş yılda yaşanan hızlı ilerlemenin arkasındaki temel gerçeklerden biri, hiç şüphesiz, sistemin büyümek için kullandığı franchise uygulamasıdır (Arman, Ekşili, Kıran ve Çetinkaya Bozkurt, 2019).

Franchisingte en önemli yönetim işlevlerinden biri, partner seçimidir. Bu seçim süreçlerinin ve bunların sonuçlarının, müşterinin işletme algısı, örgütsel iş birliği ve bir firmanın finansal performansı üzerinde potansiyel olarak geniş kapsamlı etkileri vardır. Özellikle tarafların sözleşmeye bağlı kalarak uzun süreler boyunca yükümlülüklerini yerine getirmek zorunda oldukları, tarafların iş ilişkilerinde 
genellikle önemli finansal yatırımlar yaptıkları (Clarkin ve Swavely, 2006) göz önüne alındığında partner seçiminin önemi ortaya çıkmaktadır. Alan yazında franchisingte partner seçim nedenlerini araştırmak üzere yapılan çalışmalar (Clarkin ve Swavely, 2006; Altinay, Brookes, Madanoglu ve Aktas, 2014; Brookes ve Altinay, 2011; Doherty, 2009), bu seçimi ve nedenlerini franchisor açısından ve franchisee açısından olmak üzere iki taraflı incelemektedirler. Bu araştırmada ise öncelikle Antalya ve Burdur illerinde g1da sektöründe faaliyette bulunan franchiseelerin franchise veren işletmenin seçiminde dikkate aldığı faktörlerin tespiti amaçlanmıştır. Ayrıca dikkate alınan bu faktörlerin bazı demografik değişkenlerle, franchising anlaşması sürecinde ve sonrasında yaşanan zorluklarla karşılaştırması yapılmıştır.

\section{KAVRAMSAL ÇERÇEVE}

\subsection{Franchising}

Bir stratejik ortaklık türü olan franchising, Ulusal Franchising Derneği'nin (UFRAD) tanımına göre, bir ürünün veya hizmetin imtiyaz hakkına sahip tarafın, ikinci tarafa belirli bir süre ve şartlarda iş yapma, işin yönetimi için bilgi ve destek sağlama ve imtiyaz hakkını ticari faaliyetler için verdiği, imtiyazdan doğan sürekli ve uzun dönemli bir iş birliğidir (UFRAD, t.y.). Franchisinginde; franhisor, franchise alan kişiye, markasını, ürününü ve iş sistemini belirli bir süre için belirli bir şekilde kullanma hakk1 vermektedir (Felstead, 1993). Böylece franchise sahipleri, kendini kanıtlamış bir markaya ve iş sistemine; franchisorlar ise franchise sahiplerinin yerel pazar bilgilerine erişim imkânı kazanırlar (Brookes ve Altinay, 2011). Bu durum, franchisingin tercih edilme oranını arttırmaktadır (Shane, 1996). Küçük ve orta ölçekli işletmelerin rekabet halinde olduğu ve hiçbir şirketin baskın olmadığı ortamlarda dikkat çeken bir ittifak türüdür. En gelişmiş stratejik ittifak türlerinden biri olan ve dikey entegrasyona dayalı bir franchising sözleşmesinde, franchising hakları satın alan bir şirket (franchisee), franchisor gibi yatırım yapar. Farklı bir kimliğe sahip olmasına rağmen franchise veren işletmenin yönetimi ve kontrolü altında faaliyet gösterir (Arman, Ekşili, Kıran ve Çetinkaya Bozkurt, 2019). 


\subsection{Partner Seçimi}

İki veya daha fazla ortak, ortaklığa girme konusunda karşılıklı görüşme içinde olabilse de ortaklıkla ilgili karar tipik olarak taraflardan biri tarafından başlatılır (Shah ve Swaminathan, 2008). Franchisingte bu ortaklık girişimlerini başlatan taraf franchise alan taraftır. Bu nedenle, franchisorın algılanan kısmi-çekiciliği oldukça önemlidir. Dolayısıyla bu çalışmada, franchisingi başlatan şirket perspektifinden seçim sürecindeki kriterleri incelemek amaçlanmıştır. Ayrıca francgisingte partner seçimi tarafların sözleşmeye bağlı kalarak uzun süreler boyunca yükümlülüklerini yerine getirmek zorunda oldukları, tarafların iş ilişkilerinde genellikle önemli finansal yatırımlar yaptıkları (Clarkin ve Swavely, 2006), göz önüne alındığında oldukça önemlidir. Stratejik ortaklıklarda, başarısız olmanın en yaygın nedeni, firmanın genel stratejisi ile bu stratejideki ortaklığın rolü arasındaki yakın etkileşiminin tanınmamasıdır (Koza ve Lewin, 2000). Doğru ortakların seçilmesi, franchise alanın fırsatçı davranış riskini ortadan kaldırmak, marka imajını korumak, yatırım risklerini azaltmak ve franchise sahiplerinin vaat edilen desteği vermelerini sağlamak için önemlidir (Fladmoe-Lindquist, 2000; Clarkin ve Rosa, 2005). Yapılan araştırmalar hem partner seçim sürecinin hem de partner seçim kriterlerinin önemini ortaya koymaktadır. Bununla birlikte, bu çalışmalar ortak seçimine sadece franchisor açısından bakma eğiliminde olmakla birlikte önemini vurgulamıştır (Doherty, 2009).

Franchisingte partner seçim nedenlerini araştırmak üzere yapılan birçok çalışma (Clarkin ve Swavely, 2006; Altinay, Brookes, Madanoglu ve Aktas, 2014; Brookes ve Altinay, 2011; Doherty, 2009), bu seçimi ve nedenlerini franchisor açısından ve/veya franchisee açısından olmak üzere iki taraflı incelemektedir.

Uluslararası stratejik ortaklıklarda partner seçimi ile ilgili 1970 yılında Tomlinson'ın yaptığı araştırmada, Pakistan ve Hindistan'daki İngiliz firmaların ortak seçiminde dikkate aldıkları altı adet kriter belirlenmiştir. Bu kriterler önem derecesine göre sırasıyla; uygun ortaklık geçmişi, kaynaklar, tesisler, ortak durumu, zorunlu seçim ve yerel kimliktir. Daha sonra farklı kültürlerde yapılan başka bir çalışmada (Tomlinson ve Thompson, 1977'den aktaran Brookes ve Altinay, 2011) ise seçim kriteri arasında bir fark bulunmuştur. Bu araştırmaya göre, Kanadalı ve Meksikalı ortak 
girişimlerinde finansal kaynaklar her iki şirket için de önemliyken, Kanadalı şirketler iş dünyasında uyuma, benzer amaçlara, etiğe ve hükümetle müzakere etme yeteneğine öncelik vermiştir. Meksikalı şirketlerin ise teknoloji ve deneyime, uluslararası prestije, taahhüde ve Meksikalılarla iletişim kurma yeteneğine önem verdiği tespit edilmiştir (Brookes ve Altinay, 2011). Başka bir çalışmada ise finansal yetenekler, deneyim ve yönetim becerileri, demografik özellikler ve iş boyutlarına yönelik tutumlar (algılanan yenilikçilik, kişisel gelişim arzusu, işle ilgili zorluklarla baş edebilme, işe kişisel bağlılık ve ticari risk alma) franchisörler tarafından kullanılan önemli seçim kriterleri olarak tanımlamıştır. Amerika Birleşik Devletleri'nde yapılan bu araştırmada franchisörlerin temel ölçütleri algılanan iş birliği, ticari karardan memnuniyet ve franchise alan fırsatçılığı olarak tespit edilmiştir (Jambulingham ve Nevin, 1999). Çinli şirketlerin, ortak seçiminde ortağın maddi olmayan varlıklarının yanı sıra teknolojik ve yönetsel yeteneklerine önem vererek uzun vadeli bakış açısına sahip oldukları görülmektedir. Rus firmaları ise daha az istikrarlı kurumsal ortamları nedeniyle finansal sermayeye erişim ve tamamlayıcı yetenekler gibi daha kısa vadeli hedeflere odaklanmaktadirlar (Hitt, Ahlstrom, Dacin, Levitas ve Svobodina, 2004). İngiltere'de perakende bayilerinin uluslararası franchisorları seçiminde finansal istikrar, tutumlar ve kişisel özellikler gibi kriterlere önem verdiği tespit edilmiş, bunun yanında ortaklar arasındaki “doğru kimya"nın önemli olduğu sonucuna varmışlardır (Doherty ve Alexander, 2004). Kuzey Amerika'da da benzer sonuçlara rastlanmıştır (Clarkin ve Swavely, 2006). Türkiye'de yapılan bir araştırmada ise araştırma kapsamında yer alan şirketler için partner seçiminde en önemli iki kriter "üst yönetimler arasında güven" ve "partnerin Türkiye'de bilinilirliği" olmuştur. Göreve ilişkin en önemli kriter ise "hammaddeye erişim kolaylı̆̆ı" olurken, "sermayeye erişim" daha az öneme sahip bir kriter olarak tespit edilmiştir. Bu şirketler için en önemli stratejik motivasyon "iş birliğini hızlandırmak yoluyla daha fazla istikrara (karlılığa) ulaşmak" olurken, en az öneme sahip kriter "dış çevredeki belirsizlikleri azaltmak" olarak belirlenmiştir (Çakal, 2012).

Stratejik ortaklıklarda partner seçimi araştırmalarında belirlenen çok çeşitli kriterler bulunmaktadır. Bu kriterleri anlamak için Geringer (1991) tarafından geliştirilen bir tipoloji kullanılmaktadır. Buna göre kriterler Tablo 1'de gösterildiği 
üzere görev odaklı ve partner odaklı kriterler olmak üzere iki başlık altında sinıflandirılmaktadır (Altinay, Brookes ve Aktas, 2013).

Tablo 1. Görev ve Partner Odakl1 Kriterler

\begin{tabular}{|l|l|}
\hline Görev odaklı kriterler & Partner odaklı kriterler \\
\hline$\square$ Finansal kaynaklar/sermayeye erişim & $\square$ Geçmişteki işbirliği \\
$\square$ Malzemeler/doğal kaynaklar & $\square$ Partnerin durumu \\
$\square$ Teknolojik kaynaklar & $\square$ Partnerin itibarı \\
$\square$ Yerel pazar/kültür bilgisi & $\square$ Üst yönetime duyulan güven \\
$\square$ Dağıtım kanalları/alıcılarla bağlantılar & $\square$ Tamamlayıcılı̆̆ı: \\
$\square$ Ürünler & - örgütsel veya ulusal kültür \\
$\square$ Üretim süreçleri bilgisi & - kaynaklar \\
$\square$ Yasal izinlere erişim & - pazarlama ve dağıtım sistemleri \\
$\square$ İnsan kaynağına erişim & - boyut ve yapı \\
\hline
\end{tabular}

Kaynak: Al-Khalifa and Peterson (1999); Glaister and Buckley (1997); Tatagolu (2000)' dan derleyen Altinay, Brookes ve Aktas (2013).

Partner seçimini franchiseeler açısından inceleyen çalışmalar ve bu çalışmalar sonucunda ortaya çıkan seçim kriterlerinin önem sırası Tablo 2'de gösterilmiştir. Guilloux, Gauzente, Kalika ve Dubost (2004)'un araştırmasında, franchiseelerin franchisor seçiminde önem sırasına göre, açılış öncesi destek, marka, gelişim olanağ1, franchisor desteği, kârlılık ve reklam olmak üzere görev odaklı altı kritere önem verdikleri belirlenmiştir. Ayrıca 2004 yılı önceki çalışmalarla kıyaslandı̆̆ında, gelişim imkânı kriterinin olması, franchiseelerin uzun dönemli düşünmeye başladıklarını göstermektedir. Cho (2004) ise Koreli franchaseelerin partner seçiminde, partnerin özellikleri, destek hizmetleri ve maliyeti en önemli ölçütler olarak belirlemiştir. Bu üç kriterin ilki partner odaklıyken son ikisi görev odaklıdır. Jauhari, Vaishnov ve Altinay (2009)'ın çalışmasında önem sırasına göre kârlılık, marka ve operasyon desteği en önemli kriterler olmuştur. Altinay, Brookes ve Aktas (2013)'ın araştırmasında ise ilk üç kriter görev odaklı, diğer iki kriter ise partner odaklıdır. Çalışmalar incelendiğinde görev odaklı kriterlerin yoğunlukta olduğu görülmektedir. 
Tablo 2. Franchiseelerin Franchisor Seçim Kriterleri

\begin{tabular}{|c|c|c|c|c|c|c|c|}
\hline $\begin{array}{c}\text { Önem } \\
\text { siras1 }\end{array}$ & $\begin{array}{c}\text { Altinay, } \\
\text { Brookes ve } \\
\text { Aktas } \\
\text { (2013) }\end{array}$ & $\begin{array}{c}\text { Vaishnov } \\
\text { ve Altinay } \\
(2009)\end{array}$ & Cho (2004) & \begin{tabular}{|l} 
Guilloux, \\
Gauzente, \\
Kalika ve \\
Dubost. \\
(2004)
\end{tabular} & $\begin{array}{l}\text { Withane } \\
\text { (1991) }\end{array}$ & $\begin{array}{l}\text { Peterson ve } \\
\text { Dant (1990) }\end{array}$ & $\begin{array}{l}\text { Knight } \\
\text { (1986) }\end{array}$ \\
\hline 1 & Marka & Kârlılık & $\begin{array}{l}\text { Partner } \\
\text { özellikleri }\end{array}$ & $\begin{array}{l}\text { Açlliş } \\
\text { öncesi } \\
\text { destek }\end{array}$ & $\begin{array}{l}\text { Kanitlanmış } \\
\text { konsept }\end{array}$ & $\begin{array}{l}\text { Ĕ̆itim } \\
\text { desteği }\end{array}$ & Marka \\
\hline 2 & Ürün & Marka & $\begin{array}{l}\text { Operasyon } \\
\text { desteği }\end{array}$ & Marka & Düşük risk & Marka & $\begin{array}{l}\text { Tatmin } \\
\text { edicilik }\end{array}$ \\
\hline 3 & $\begin{array}{l}\text { Franchisor } \\
\text { desteği }\end{array}$ & $\begin{array}{l}\text { Operasyon } \\
\text { desteği }\end{array}$ & Maliyet & $\begin{array}{l}\text { Gelişim } \\
\text { imkanı }\end{array}$ & İsim hakk1 & Bağımsızlık & Bağımsızlık \\
\hline 4 & Güven & & & $\begin{array}{l}\text { Operasyon } \\
\text { desteği }\end{array}$ & $\begin{array}{l}\text { Başlangiç } \\
\text { desteği }\end{array}$ & $\begin{array}{l}\text { Yatırım } \\
\text { avantaj1 }\end{array}$ & $\begin{array}{l}\text { Gelişim } \\
\text { imkanı }\end{array}$ \\
\hline 5 & Güvenilirlik & & & Kârlılık & $\begin{array}{l}\text { Franchisor } \\
\text { desteği }\end{array}$ & \begin{tabular}{|l|} 
Düşük \\
yatırım \\
maliyeti
\end{tabular} & $\begin{array}{l}\text { Kanitlanmış } \\
\text { konsept }\end{array}$ \\
\hline 6 & & & & Reklam & $\begin{array}{l}\text { Hizlı } \\
\text { kurulum }\end{array}$ & 3 & $\begin{array}{l}\text { Yatırım } \\
\text { avantaj1 }\end{array}$ \\
\hline
\end{tabular}

Kaynak: Guilloux, Gauzente, Kalika ve Dubost (2004) ve Altinay, Brookes ve Aktas (2013) den derlenmiştir.

Bu araştırmada Antalya ve Burdur illerinde gıda sektöründe faaliyette bulunan franchiseelerin franchise veren işletmenin seçiminde dikkate aldığ faktörlerin tespiti amaçlanmıştır. Ayrıca dikkate alınan bu faktörlerin işletme ölçeği ve bulunduğu il değişkenlerine göre farklılaşma durumu incelenmiş ve yine bu faktörlerin franchising anlaşması sürecinde ve sonrasında yaşanan zorluklarla karşılaştırması yapılmıştır.

\section{YÖNTEM}

Araştırma; amacına uygun olarak nitel araştırma yöntemlerinden fenomonoloji araştırma desenine uygun bir şekilde dizayn edilmiş ve içerik analizi gerçekleştirilmiştir. Görüşmelere başlamadan önce ilgili literatürden yararlanılarak bir soru formu oluşturulmuştur. Mart 2018 tarihinde veri toplanmaya başlanmış ve bu süreç Haziran 2019 tarihinde tamamlanmıştır. Verilerin 1 Ocak 2020 tarihinden önce toplanması nedeniyle etik kurul izin belgesi alınmasına gerek duyulmamıştır. Bu süreçte Antalya ve Burdur illerinde gıda sektöründe faaliyette bulunan franchiseeler ile yüz yüze görüşmeler yapılmış ve toplanan veriler kayıt altına alınmıştır. Daha sonra ilgili literatür dikkate alınarak veriler kodlanmıştır. Ardından oluşturulan kodlara göre kategoriler belirlenmiş ve kodlarla kategoriler düzenlenmiştir. Son 
olarak, bulgular tanımlanmış ve yorumlamalar yapılmıştır (Yıldırım ve Şimşek, 2016). Verilerin analizinde MAXQDA 18.0 programı kullanılmıştır.

\section{1. Çalışmanın Amacı}

Bu araştırmada öncelikle Antalya ve Burdur illerinde gıda sektöründe faaliyette bulunan franchiseelerin franchise veren işletmenin seçiminde dikkate aldiğ 1 faktörlerin tespiti amaçlanmıştır. Ayrıca dikkate alınan bu faktörler bazı demografik değişkenler ile franchising anlaşması sürecinde ve sonrasında yaşanan zorluklarla karşılaştırması yapılmıştır. Çalışma sonucunda ulaşılan bulguların franchise veren işletmenin seçiminde dikkat edilmesi gereken faktörlere 1şı tutacağ1 düşünülmektedir. Ayrıca bulgular sayesinde franchise veren işletmelerin kendilerinde geliştirmeleri gereken öncelikli alanları daha net saptayabileceklerine inanılmaktadır.

\subsection{Veri Kaynağı ve Çalışma Grubu}

Araştırmanın veri kaynağını Antalya ve Burdur illerinde gıda sektöründe faaliyet gösteren toplam 16 franchisee ile yapılan yüz yüze görüşmeler oluşturmaktadır. Türkiye'de franchise sisteminin gida sektöründe yaygın olarak kullanılması (Alkan, 2015) bu sektörün tercih edilmesinde etkili olmuştur. Görüşmelere başlamadan önce ilgili literatür taranmış ve bir soru formu oluşturulmuştur. Franchisee işletmeleriyle yapılan mülakatlarda derinlemesine bilgi almak adına yarı-yapılandırılmış görüşme tekniği kullanılmıştır. Örneklem kolayda ve kartopu örneklem yöntemiyle oluşturulmuştur. Cevapların tekrarlanması ile birlikte görüşmelerin doyuma ulaştığ1 görülmüş ve mülakatlar bitirilmiştir. Araştırma kapsamında incelenen 16 işletmeye dair detaylı bilgi Tablo 3’te yer almaktadır. 
Tablo 3. Çalışma Grubuna İlişkin Bilgiler

\begin{tabular}{|c|c|c|c|}
\hline Ĕgitim Düzeyi & Frekans & Sektör & Frekans \\
\hline Lisans ve üstü & 10 & Yiyecek & 9 \\
\hline Lisans alt1 & 6 & İçecek & 7 \\
\hline Şehir & & İş Tecrübesi & \\
\hline Antalya & 8 & G1da Sektöründe Tecrübesiz & 11 \\
\hline Burdur & 8 & G1da Sektöründe Tecrübeli & 5 \\
\hline Ölçek & & Çalışan Sayısı & \\
\hline Ulusal & 9 & 10 ve alt & 8 \\
\hline Uluslararası & 7 & 10 üzeri & 8 \\
\hline Kişinin Yaşı & & Kurulma Y1lı & \\
\hline $18-29$ & 4 & 2014 yılından önce & 2 \\
\hline $30-34$ & 4 & $2014-2016$ & 3 \\
\hline $35-39$ & 5 & $2016-2018$ & 7 \\
\hline 40 ve üstü & 3 & 2018 yılından sonra & 4 \\
\hline $\begin{array}{ll}\text { Önceki } & \text { Franchise } \\
\text { Tecrübesi } & \\
\end{array}$ & & Memnuniyet Düzeyi & \\
\hline Yok & 13 & Memnun & 11 \\
\hline Var & 3 & Memnun Değil & 5 \\
\hline \multicolumn{4}{|l|}{ Faaliyet Durumu } \\
\hline Faaliyette & 10 & 7 & \\
\hline Faaliyette Değil & 6 & s & \\
\hline
\end{tabular}

Tablo 3'te görüldüğü üzere katılımcıların çoğu lisansüstü eğitimine sahiptir. 9 işletme yiyecek, 7 işletme ise içecek üzerine yoğunlaşmıştır. İşletmelerin 8'i Antalya ve 8'i de Burdur ilinde faaliyet göstermektedir. Katılımcıların çoğunun gıda sektöründe tecrübesi yoktur. 9 işletme ulusal ölçekte iken çalışan sayısı 10 ve altı ile 10 üzeri olan işletme sayısı eşittir. İşletme sahiplerinin yaşları dikkate alındığında genellikle 40 yaş altı olduğu görülmektedir. 18-29 yaş arasında 4 kişi, 30-34 yaş arasında 4 kişi, 35-39 yaş arasında 5 kişi ve 40 yaş ve üstü 3 kişi bulunmaktadır. Katılımcıların çoğunun 2016-2018 yıllarında kurulduğu ve franchise tecrübelerinin olmadığ1 saptanmıştır. Franchiseelerin neredeyse hepsinin memnun olduğu tespit edilmiştir. Katılımcılarla görüşmeler 2018 yılında gerçekleşmiş olup 2019 yılında faaliyet durumu da araştırma kapsamına alınmıştır. Katılımcıların 6 tanesinin faaliyette olmadığı görülmüştür. 


\section{BULGULAR}

\subsection{Franchise Veren İşletmelerin Belirlenmesinde Etkili Olan Faktörlere Yönelik Bulgular}

Araştırma kapsamında yapılan görüşmelere göre franchisor seçiminde girişimcilerin farklı stratejileri bulunmaktadır. Bazı franchiseeler daha çok görev odaklı bir şekilde araştırmalarını gerçekleştirirken diğerleri partner odaklı bir yaklaşımla ikili ilişkileri ve güveni ön planda tutmuştur. Franchiseelerin sahip olduğu tutumların daha açık bir şekilde gösterilmesi için franchiseelerin yorumlarından alıntılar verilmiştir.

A: “Katkı maddesi yok. Bağımlılık yapan ürünler yok. Doğal. Almış olduğu sertifikalar da etkili oldu. Ayrıca franchisor her il için bir kişiye franchise veriyor ve sinırlı sayıda şube açma hakkı tanıyor..."

B: “Açıldığında Türkiye'de 3. kahveci firmasıydı... 160'a yakın şubesi oldu şu an. Ayrıca, Antalya menşeili bir firma. Direkt yerlerini, üretim bantlarmı gördüğümüz bir yer. Ürün tadı konusunda daha önce beğendiğimiz bir yer. Ek olarak; öğrencinin beğeneceği dekorasyona sahip olması da etkiledi. Genelde bizim hitap ettiğimiz kişiler öğrenci...".

C: “Tesadüfen oldu. Bölge müdürü ile tanıştık araştırmaya başladık. Franchisora ulaşılabilir, şartları ă̆ır değil. Piyasadaki ürünlere alternatif."

D: “Yöneticiler çok önemli, elektriğin tutması çok önemli ilk başta. Kullanılan ürünlerin kaliteli olması önemli. Mesela dışarıda bir ürünü 15 liradan alırsınız. Benim aldığım ürün 20'den aşă̆ıda değil. Kaliteli ürün. Biliyorsunuz şu andaki en büyük hile gıda sektöründe. Burada önemli olan sertifikadan ziyade, güven."

Araştırma kapsammda franchiseelerin tercihleri içerik analizi ile incelendiğinde ise dikkate alınan kriterler ve bu kriterlerin önem sırası ortaya çıkarılmıştır. Bulgular Şekil 1'de gösterilmiştir. Şekil 1'e göre franchise alan işletmelerin en fazla dikkat ettiği faktörün konsept - ürün çeşitliliği olduğu görülmüştür. Ardından sırasıyla ikili ilişkiler, marka, firma potansiyeli, profesyonellik, ürün ve hizmet standardı, yatırım şartlarının uygunluğu, kârlılık oranı ve lojistik desteğin dikkat edilen unsurlar olduğu tespit edilmiştir. 


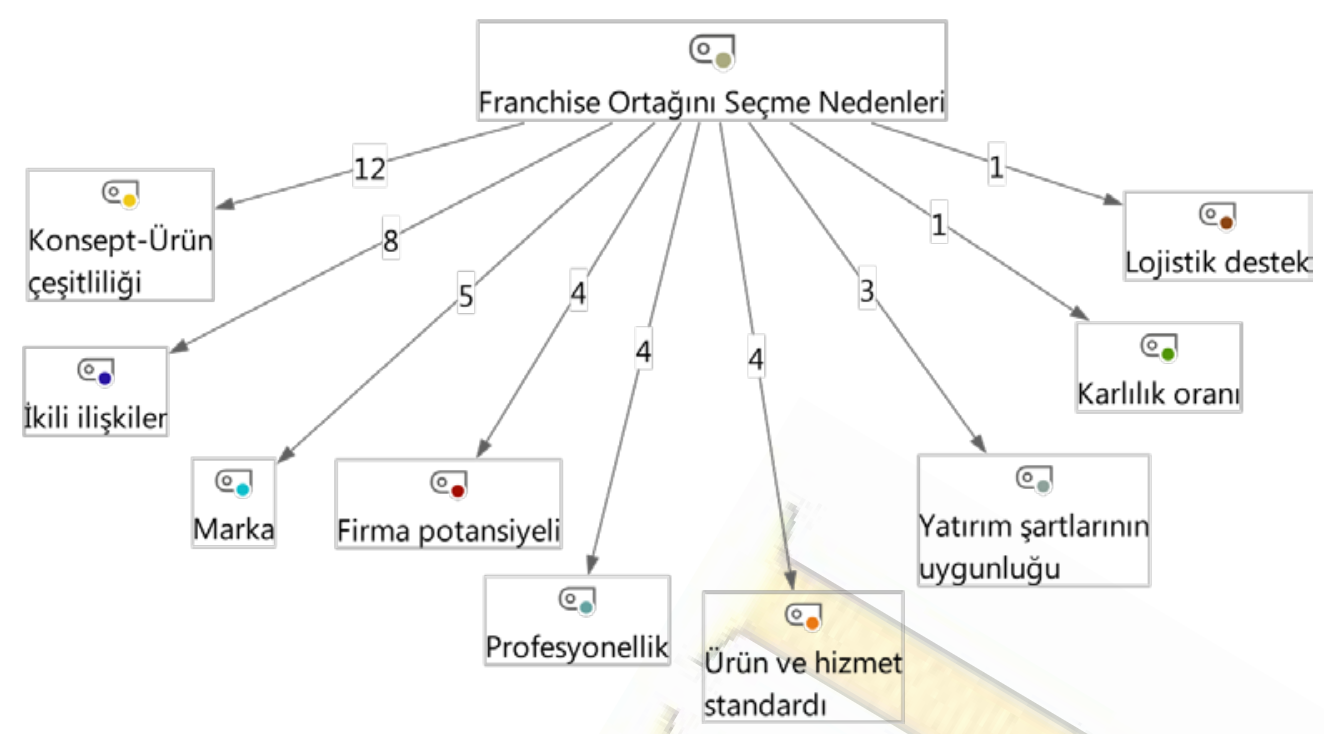

Şekil 1. Franchise Veren İşletmelerin Belirlenmesinde Etkili Olan Faktörler Kaynak: Yazarlar tarafından üretilmiştir.

\subsection{Franchise Veren İşletmelerin Belirlenmesinde Etkili Olan Faktörlerin Bazı}

\section{Demografik Değişkenlere Göre Farklılaşıp Farklılaşmadığına Dair Bulgular}

Araştırma kapsamında franchisor seçiminde dikkat edilen etmenlerin bazı demografik değişkenlere göre farklılaşıp farklılaşmadığı incelenmiştir. İlk olarak sektör ayırımı yapılmıştır. Gıda işletmeleri üzerine yapılan çalışmada yiyecek ve içecek üzerinde yoğunlaşan işletmeler çalışılmış ve sonuçlar Şekil 2'de gösterilmiştir.

Şekil incelendiğinde içecek sektörü için konsept-ürün çeşitliliğinin oldukça yüksek bir öneme sahip olduğu görülmektedir. İçecek sektöründe faaliyet gösteren katılımcıların tümü (7 işletme) konsept-ürün çeşitliliğini dikkate almıştır. İkili ilişkilerin, firma potansiyelinin, markanın ve lojistik desteğin içecek sektöründekiler için daha etkili olduğu görülürken, profesyonellik, yatırım şartlarının uygunluğu ile ürün ve hizmet standardının yiyecek sektöründe daha fazla dikkate alındığı görülmektedir. 


\begin{tabular}{|c|c|c|c|}
\hline & Yiyecek & İçecek & Toplam \\
\hline \multicolumn{4}{|l|}{$\triangle$ @ franchise ortağını seçme nedenleri } \\
\hline ○ Konsept-Ürün çeşitliliği & 5 & 7 & 12 \\
\hline ๑ Íkili ilişkiler & 4 & 4 & 8 \\
\hline Firma potansiyeli & 2 & 2 & 4 \\
\hline$\odot_{\odot}$ Profesyonellik & 3 & 1 & 4 \\
\hline ๑ Yatırım şartlarının uygunluğu & 3 & & 3 \\
\hline ๑ Ürün ve hizmet standardı & 3 & 1 & 4 \\
\hline$\odot$ Marka & 2 & 3 & 5 \\
\hline$\odot$ Karlılık oranı & 1 & & 1 \\
\hline$\bigodot_{\bullet}$ Lojistik destek & & 1 & 1 \\
\hline$\Sigma$ TOPLAM & 23 & 19 & 42 \\
\hline \# N (Belgeler) & $9(56 \%)$ & $7(43 \%)$ & $16(100 \%)$ \\
\hline
\end{tabular}

Şekil 2. Franchisor Seçiminin Sektörel Dağılımı

Kaynak: Yazarlar tarafından üretilmiştir.

Franchising uygulamasını tercih etme sebeplerinden biri franchisorın önceki tecrübelerinden faydalanmaktır (Tutar 2005: 77). Araştırmada da franchising uygulamasını tercih eden girişimcilerin tecrübe durumu incelenmiş ve Şekil 3'de gösterilmiştir. Şekil 3'e göre gıda sektöründe tecrübeli olan işletme sayısının beş olduğu, tecrübesiz işletme sayısının ise on bir olduğu görülmektedir. Tecrübeli işletmelerin hepsi konsept- ürün çeşitliliğini dikkate aldığı ve tecrübesiz girişimcilere göre profesyonelliğe, markaya ve kârlılık oranına önem veren işletme oranının daha yüksek olduğu görülmektedir. Tecrübesiz işletmelerin ise tecrübeli işletmeler kadar olmasa dahi konsept-ürün çeşitliliğini inceleyen işletme oranının ve ikili ilişkilere önem veren işletme oranının yüksek olduğu saptanmıştır.

\begin{tabular}{|c|c|c|c|}
\hline & Gıda sektöründe tecrübesiz & Gıda sektöründe tecrübeli & Toplam \\
\hline$\Delta \odot$ franchise ortağını seçme nedenleri & & & \\
\hline ๑ Konsept-Ürün çeşitliliği & 7 & 5 & 12 \\
\hline @ İkili ilişkiler & 6 & 2 & 8 \\
\hline • Firma potansiyeli & 3 & 1 & 4 \\
\hline$\varrho_{\odot}$ Profesyonellik & 2 & 2 & 4 \\
\hline ๑ Yatırım şartlarının uygunluğu & 2 & 1 & 3 \\
\hline ๑ Ürün ve hizmet standardı & 3 & 1 & 4 \\
\hline 巳e Marka & 3 & 2 & 5 \\
\hline Carlılık oranı & & 1 & 1 \\
\hline$\odot$ Lojistik destek & 1 & & 1 \\
\hline$\Sigma$ TOPLAM & 27 & 15 & 42 \\
\hline \# N (Belgeler) & $11(68 \%)$ & $5(31 \%)$ & $16(100 \%)$ \\
\hline
\end{tabular}

Şekil 3. Franchisor Seçiminin Tecrübe Durumuna Göre Dağılımı 
Araştırma kapsamında ayrıca franchiseelerin daha önce franchising uygulamasını tercih edip etmedikleri araştırılmış ve franchisor seçiminde bir farklılaşma yaratıp yaratmadığı incelenmiştir. Sonuçlar Şekil 4'de yer almaktadır. Şekil 4'e göre daha önce franchising uygulamasını deneyimleyen işletme sayısı üç iken franchising tecrübesi bulunmayan işletme sayısı on üçtür. Tecrübeli girişimcilerin hepsi sektör tecrübesinde olduğu gibi seçimlerini yaparken konsept ürün çeşitliliğini dikkate almışlardır. Ayrıca üç işletmenin ikisinde marka ve birinde ikili ilişkiler seçimlerinde etkili olmuştur. Daha önce franchising tecrübesi olmayan işletmelerin ise konsept ürün çeşitliliğinin yanında, franchising ortağını seçme nedeni olarak ikili ilişkilere de önem verdiği ortaya çıkmıştır.

\begin{tabular}{|c|c|c|c|}
\hline & Yok & Var & Toplam \\
\hline \multicolumn{4}{|l|}{ ๑ franchise ortağını seçme nedenleri } \\
\hline ๑ Konsept-Ürün çeşitliliği & 9 & 3 & 12 \\
\hline$\bullet$ İkili ilişkiler & 7 & 1 & 8 \\
\hline$\bullet$ Firma potansiyeli & 4 & & 4 \\
\hline ๑Profesyonellik & 4 & & 4 \\
\hline ๑ Yatırım şartlarının uygunluğu & 3 & & 3 \\
\hline$\odot$ Ürün ve hizmet standardı & 4 & & 4 \\
\hline ๑- Marka & 3 & 2 & 5 \\
\hline$\odot$ Karlılık oranı & 1 & & 1 \\
\hline$\odot$ Lojistik destek & 1 & & 1 \\
\hline$\Sigma$ TOPLAM & 36 & 6 & 42 \\
\hline \# N (Belgeler) & $13(81 \%)$ & $3(18 \%)$ & $16(100 \%)$ \\
\hline
\end{tabular}

Şekil 4. Franchisor Seçiminin Franchising Tecrübesine Göre Dağılımı

Kaynak: Yazarlar tarafından üretilmiştir.

Tercih edilen franchisorların ölçekleri incelenmiş ve sonuçlar Şekil 5'te gösterilmiştir. Şekil 5'te franchisor seçiminde işletmelerin dokuzunun ulusal düzeyde yedisinin ise uluslararası düzeyde faaliyet gösteren firmaları tercih ettiği görülmektedir. Ulusal marka tercih sebepleri incelendiğinde yatırım koşullarının uygunluğu dikkat çekmektedir. Sadece ulusal marka tercihinde bulunan işletmeler bu kriteri dile getirmişlerdir. İkili ilişkilere hem ulusal hem de uluslararası işletmeler dikkate almış olmakla birlikte ulusal ölçekteki girişimciler için daha önemli olduğu görülmüştür. Öte yandan partner seçiminde tercih nedenleri firma sayılarına oranları göz önüne alındığında uluslararası marka tercihinde bulunan girişimcilerin diğer 
işletmelere göre konsept ürün çeşitliliği, firma potansiyeli, profesyonellik ve marka kriterlerini nispeten daha fazla ön planda tuttuğu tespit edilmiştir.

\begin{tabular}{|c|c|c|c|}
\hline & Ulusal & Uluslararası & Toplam \\
\hline \multicolumn{4}{|l|}{$\Delta$ @ franchise ortağını seçme nedenleri } \\
\hline ๑ Konsept-Ürün çeşitliliği & 6 & 6 & 12 \\
\hline ๑ İkili ilişkiler & 6 & 2 & 8 \\
\hline$\bigodot_{\bullet}$ Firma potansiyeli & 2 & 2 & 4 \\
\hline ๑Profesyonellik & 1 & 3 & 4 \\
\hline ఠ Yatırım şartlarının uygunluğu & 3 & & 3 \\
\hline$\bigodot_{\odot}$ Ürün ve hizmet standardı & 3 & 1 & 4 \\
\hline ๑ Marka & 2 & 3 & 5 \\
\hline$\varrho_{\bullet}$ Karlılık oranı & & 1 & 1 \\
\hline$\oslash_{\text {Lojistik destek }}$ & 1 & & 1 \\
\hline$\sum$ TOPLAM & 24 & 18 & 42 \\
\hline \# N (Belgeler) & $9(56 \%)$ & $7(43 \%)$ & $16(100 \%$ \\
\hline
\end{tabular}

Şekil 5. Franchise Veren İşletme Seçiminin Ölçeğe Göre Dağılımı

Kaynak: Yazarlar tarafından üretilmiştir.

Ayrıca karşılaştırma yapmak amacıyla iki farklı il araştırma kapsamına alınmıştır. Şekil 6'ya göre iki il arasındaki franchise veren işletme seçimi kriterleri birbirine benzemektedir.

\begin{tabular}{|c|c|c|c|}
\hline & Antalya & Burdur & Toplam \\
\hline \multicolumn{4}{|l|}{$\triangle$ ę franchise ortağını seçme nedenleri } \\
\hline ๑ Konsept-Ürün çeşitliliği & 6 & 6 & 12 \\
\hline$\bullet$ İkili ilişkiler & 4 & 4 & 8 \\
\hline$\bullet$ Firma potansiyeli & 3 & 1 & 4 \\
\hline$\odot$ Profesyonellik & 3 & 1 & 4 \\
\hline ๑ Yatırım şartlarının uygunluğu & 2 & 1 & 3 \\
\hline$\odot_{\bullet}$ Ürün ve hizmet standardı & 1 & 3 & 4 \\
\hline$\odot$ Marka & 3 & 2 & 5 \\
\hline$\odot$ Karlılık oranı & 1 & & 1 \\
\hline$\odot$ Lojistik destek & & 1 & 1 \\
\hline$\Sigma$ TOPLAM & 23 & 19 & 42 \\
\hline \# N (Belgeler) & $8(50 \%)$ & $8(50 \%)$ & $16(100 \%)$ \\
\hline
\end{tabular}

Şekil 6. Franchise Veren İşletme Seçiminin Bulundukları Şehre Göre Dağılımı

Kaynak: Yazarlar tarafından üretilmiştir. 
Araştırma kapsamında katılımcıların eğitim durumu incelenmiştir. Katılımcıların altısının lisans altı, onunun ise lisansüstü mezuniyeti olduğu görülmüştür. Lisansüstü mezuniyete sahip bireylerin genellikle konsept-ürün çeşitliliğine öncelik verdiği, lisans altı mezuniyeti olan bireylerin ise ikili ilişkilere yöneldiği tespit edilmiştir (Şekil 7).

\begin{tabular}{|c|c|c|c|}
\hline & Lisans altı & Lisans ve üstü & Toplam \\
\hline \multicolumn{4}{|l|}{$\Delta$ @e franchise ortağını seçme nedenleri } \\
\hline ๑ Konsept-Ürün çeşitliliği & 3 & 9 & 12 \\
\hline$\bullet$ İkili ilişkiler & 4 & 4 & 8 \\
\hline$\bullet$ Firma potansiyeli & 1 & 3 & 4 \\
\hline$\odot$ Profesyonellik & 1 & 3 & 4 \\
\hline • Yatırım şartlarının uygunluğu & 2 & 1 & 3 \\
\hline ๑Ürün ve hizmet standardı & 2 & 2 & 4 \\
\hline @ Marka & 1 & 4 & 5 \\
\hline$\odot$ Karlılık oranı & & 1 & 1 \\
\hline Lojistik destek & & 1 & 1 \\
\hline$\Sigma$ TOPLAM & 14 & 28 & 42 \\
\hline \# N (Belgeler) & $6(37 \%)$ & $10(62 \%)$ & $16(100 \%)$ \\
\hline
\end{tabular}

Şekil 7. Franchisor Seçiminin Eğitim Düzeyine Göre Dağılımı

Kaynak: Yazarlar tarafından üretilmiştir.

Franchise ortağını seçtikten sonraki süreçte bireylerin franchisor seçimlerinden memnuniyet durumu araştırılmış ve on bir işletmenin memnun olduğu tespit edilmiştir. Konu hakkında bilgi veren Şekil 8 incelendiğinde memnun olmayan işletmelerin neredeyse hepsinin ikili ilişkileri dikkate aldığı görülmektedir. Ayrıca yatırım şartlarının uygunluğunu dikkate alan işletmelerin hepsinin memnun olmadığı saptanmıştır. 


\begin{tabular}{|c|c|c|c|}
\hline & Memnun değil & Memnun & Toplam \\
\hline \multicolumn{4}{|l|}{$\Delta \odot$ franchise ortağını seçme nedenleri } \\
\hline ○ Konsept-Ürün çeşitliliği & 3 & 9 & 12 \\
\hline$\bullet$ İkili ilişkiler & 4 & 4 & 8 \\
\hline$\bullet$ Firma potansiyeli & 1 & 3 & 4 \\
\hline$\odot$ Profesyonellik & 1 & 3 & 4 \\
\hline • Yatırım şartlarının uygunluğu & 3 & & 3 \\
\hline ๑ Ürün ve hizmet standardı & 1 & 3 & 4 \\
\hline$\odot$ Marka & 1 & 4 & 5 \\
\hline$\bullet$ Karlılık oranı & & 1 & 1 \\
\hline - Lojistik destek & & 1 & 1 \\
\hline$\Sigma$ TOPLAM & 14 & 28 & 42 \\
\hline \# N (Belgeler) & $5(31 \%)$ & $11(68 \%)$ & $16(100 \%)$ \\
\hline
\end{tabular}

Şekil 8. Franchisor Seçiminin Memnuniyet Düzeyine Göre Dağılımı Kaynak: Yazarlar tarafından üretilmiştir.

Franchiseelerin franchise veren işletme seçimi yapmalarının ardından yapılacak görüşmeler sırasında zorluk yaşayıp yaşamadıkları incelenmiş ve konuya dair bulgular Şekil 9'de gösterilmiştir. Girişimciler görüşmeler sırasında sırasıyla finansman, franchisee kimliği, sözleşmenin tek taraflı olması, yer seçimi ve franchisee olarak faaliyete başlama süresinin uzun olması gibi problemlerle karşılaşmışlardır. Katılımcıların bir kısmı birden fazla sorun yaşamış olduğunu bildirmiştir. Bu durum Şekil 7'de katılımcı sayısından daha fazla belgenin bulunmasına neden olmuştur. Öte yandan sorun yaşamadığını bildiren bir işletme bulunmaktadır. Bu işletmenin ise seçimini sadece konsept-ürün çeşitliliğine göre karar verdiği görülmektedir.

İşletmelerin franchising uygulamasına başlamalarının ardından yaşamış oldukları zorluklar Şekil 10'da yer almaktadır. Şekil 10’a göre franchiseeler sırasıyla yanıltıcı/yetersiz danışmanlık, sözleşme şartlarına hâkim olamamak, tedarik ve franchise veren işletmenin yeterli tecrübesinin olmamasından kaynaklı zorluklarla karşılaştıklarını ifade etmişlerdir. Bir işletme sadece tek bir zorlukla karşılaştığını belirttiği gibi birden fazla zorluk da dile getiren işletmeler bulunmaktadır. Bu nedenle Şekil 8'de yer alan belge sayısı toplam görüşülen kişi sayısından daha fazla görünmektedir. Öte yandan hiç zorluk yaşamadığını dile getiren dört işletme bulunmaktadır. Zorluk yaşamayan işletmelerin hepsi konsept -ürün çeşitliliğini seçimlerinde dikkate almışlardır. Marka yine nispeten önem vermiş oldukları faktörler 
arasındadır. Fakat girişimciler firma büyüme potansiyeli ve yatırım şartlarının uygunluğu konularını hiç dikkate almamışlardır. 
Araştırma verilerinin toplanmasının ardından yaklaşık 1 sene sonra katılımcıların faaliyet durumu araştırılmıştır. Araştırma kapsamında görüşülen on altı firmanın onu faaliyetlerini sürdürürken altısı girişimcilerini sonlandırmak durumunda kalmışlardır (Şekil 11). Faaliyette olmayan işletmelerin franchisor seçme sebeplerinde faaliyette olan işletmelere oranlandı̆̆ında firmanın büyüme potansiyeline daha fazla odaklandığı saptanmıştır. Faaliyette olan firmaların ise nispeten daha fazla ikili ilişkiler ve marka konusunu irdelediği görülmüştür.

\begin{tabular}{|c|c|c|c|}
\hline & Faaliyette değil & Faaliyette & Toplam \\
\hline \multicolumn{4}{|l|}{$\triangleleft$ franchise ortağını seçme nedenleri } \\
\hline ¿ Konsept-Ürün çeşitliliği & 5 & 7 & 12 \\
\hline$\bullet$ İkili ilişkiler & 2 & 6 & 8 \\
\hline Firma potansiyeli & 3 & 1 & 4 \\
\hline$\odot$ Profesyonellik & 1 & 3 & 4 \\
\hline ๑ Yatırım şartlarının uygunluğu & 1 & 2 & 3 \\
\hline$\odot_{\odot}$ Ürün ve hizmet standardı & 1 & 3 & 4 \\
\hline ๑ Marka & 1 & 4 & 5 \\
\hline$\odot$ Karlılık oranı & & 1 & 1 \\
\hline$\odot$ Lojistik destek & & 1 & 1 \\
\hline$\Sigma$ TOPLAM & 14 & 28 & 42 \\
\hline \# N (Belgeler) & $6(37 \%)$ & $10(62 \%)$ & $16(100 \%)$ \\
\hline
\end{tabular}

Kaynak: Yazarlar tarafından üretilmiştir.

Şekil 11. Franchisor Seçiminin Faaliyet Durumuna Göre Dağılımı

\section{SONUÇ VE ÖNERİLER}

Günümüzde işletmeler için küreselleşme, teknoloji ve bilgi çağının etkisiyle pazarda tutunmanın zorlaştığı aşikardır. Özellikle ilk işlerini kurma düşüncesine sahip olan girişimcilerin, rekabetin işletmeleri zorladiğı pazarlarda sürdürülebilirlikleri oldukça düşüktür. Bu açıdan franchising sistemi sağladığ1 avantajlar sayesinde girişimcilerin şanslarını arttırabilmektedir. Potansiyel müşteri kitlesine sahip olarak, sistematik bir yapının bulunduğu ve ihtiyaç duyulan desteğin sürekli sağlandığı bir ortamda girişimcilik faaliyetlerinde bulunmak riski azaltacaktır. Öte yandan başarılı olmayan bir ortak, başka bir deyişle franchise veren işletmenin seçimi ise girişimci için karşılığını alamadığı bir yatırıma dönüşebilmektedir. Bu kapsamda hazırlanan çalışmada franchiseelerin franchise veren işletme seçimleri incelenmiş ve demografik değişkenlere göre seçimlerin farklılaşıp farklılaşmadı̆̆ının 
saptanması ve franchiseelerin franchising görüşmeleri sırasında ve sonrasında yaaşdığı zorluklarla karşılaştırılması amaçlanmıştır.

Franchiseelerin en fazla dikkat ettiği faktörlerin sırasıyla konsept - ürün çeşitliliği, ikili ilişkiler, marka, firma potansiyeli, profesyonellik, ürün ve hizmet standardı, yatırım şartlarının uygunluğu, kârlılık oranı ve lojistik desteğin dikkat edilen unsurlar olduğu saptanmıştır. Konu ile yapılan diğer çalışmalar incelendiğinde ise markanın en fazla üzerinde durulan faktör olduğu görülmektedir (Altinay, Brookes ve Aktas, 2013). Ayrıca gıda sektöründeki firmaların franchising uygulamasını tercih etmesinde markalaşmanın en büyük itici güç olduğu tespit edilmiştir (Seven, 2007; Arman, Ekşili, Kıran ve Çetinkaya Bozkurt, 2019). Her ne kadar yapılan çalışmanın sonuçlarında marka ilk sıralarda yer alsa da konsept ve ürün çeşitliliği ile ikili ilişkiler araştırmanın yapıldığı örneklemde markanın önüne geçmiştir. Öte yandan ürünün kendisinin ön plana çıktığı da görülmektedir. Örneğin; ürünü farklı açılardan inceleyen franchiseeler, ürünün kalitesi, özellikle gıda sektöründe ürünün temiz, sağlıklı ve güvenli olması ya da ürünün alışveriş merkezine girmeyi sağlama gibi bir pazar fırsatı sunmasından dolayı tercih edildiğini dile getirmektedirler (Altinay, Brookes ve Aktas, 2013). Ürün çeşitliliği ve ürün hizmet standardı diğer çalışmalarda olduğu gibi bu çalışmada da franchise veren işletmenin seçiminde öne çıkmaktadır.

Franchiseelerin seçiminde içecek ve yiyecek alanında uzmanlaşmış işletmeler açısından bir farklılaşma olup olmadığı incelendiğinde yiyecek sektöründeki işletmelerin, profesyonellik, yatırım şartlarının uygunluğu ile ürün ve hizmet standardı üzerinde daha çok durduğu görülmüştür. Bu kriterlerin ise yiyecek sektörünü tercih eden girişimcilerin daha objektif bir değerlendirmeye yönelttiği düşünülmektedir. İçecek sektöründe ise konseptin tercih edileceğine inanıldığ1 markalar öne çıkmıştır. İçecek sektöründeki bu farklılığın sebebinin ise daha çok kahve üzerine yoğunlaşan işletmelerin araştırma kapsamına alınmış olması olduğu düşünülmektedir. Kahve dükkanları toplumsallığı, zevki ve paylaşımı çağrıştırırken günümüzde değişime uğramış ve farklı kahve türlerinin, değişik tat ve görünümde sunulduğu, kahve dişında alternatif içeceklerin ve yiyeceklerin de servis edildiği mekânlar haline gelmiştir. (Akarçay, 2012 s. 186 aktaran Aşık, 2017). Aşık (2017) 
çalışmasında marka kahve tercihinde en önemli unsurların sırasıyla tat ve sunum, fiyat, hizmet kalitesi ile servis hızı, kahve çeşidinin fazla olması ve dükkânın dekorasyonu olduğunu dile getirmiştir. Dolayısıyla katılımcıların konsept - ürün çeşitliliğine vermiş oldukları önemin doğruluğu görülürken özellikle marka kahve dükkanları üzerine yoğunlaşacak franchiseelerin ürün ve hizmet standardına da dikkat etmeleri önerilmektedir.

Franchiseelerin sahip olduğu deneyim incelendiğinde hem sektör hem de franchising uygulaması açısından deneyimli olan işletmelerin sayısının az olduğu görülmektedir. Bu bulgu beklenen bir sonuçtur. Tasarruflarıyla kendi işini kurmak isteyen öte yandan kendi işini kurmak için gerekli olan yetenek, güven veya tecrübeye sahip olmayan bireyler, franchising sistemi ile birlikte yeni bir iş kurma kararına oranla daha avantajlı hale gelmektedirler (Aslanoğlu, 2007: 81). Bireyler daha önce bilmediği bir alanda mal ve hizmet üreterek satabilecek seviyeye ulaşmaktadırlar (Tuncay, 1992: 51'den aktaran Kurt ve Korkmazyürek, 2019: 31). Franchiseelerin zamanla deneyim kazanması ve franchisorların desteğine eskisi gibi gerek kalmaması franchising sözleşmesinin ilk dönemlerindeki yüksek iş birliği seviyesinin zamanla düşmesine neden olduğu saptanmıştır. (Clarkin ve Swavely, 2006: 134-135). Dolayısıyla deneyimli işletmeler franchisorla bir bağ kurmamaya deneyimsiz işletmelere göre daha fazla eğilimli olacaklardır. Franchisor açısından konu incelendiğinde ise deneyimsiz girişimcilerin franchisee olarak seçilmesi bazı franchisorlar tarafindan avantajlı olarak görülmektedir. Franchisorlar için franchiseelerin eski alışkanlıkları bir tarafa bıraktırarak eğitim vermenin problemli bir süreç oluşturduğunu savunan çalışmalar mevcuttur (Clarkin ve Swavely, 2006). Bu durum deneyimli girişimcilerin franchising uygulamasını tercih etmede bir engel oluşturacaktır. Öte yandan farklı görüşe sahip olan çalışmalar da bulunmaktadır. Örneğin geçmiş deneyimlerin franchiseelerin yeteneklerini geliştirme konusunda yardımcı olduğunu gösteren çalışmalar vardır (Clarkin ve Swavely, 2006). Jambulingham ve Nevin (1999) çalışmasında franchisorların franchisee seçim sürecinde franchiseenin önceki deneyimlerinin anahtar etmen olduğunu belirtmişlerdir. Araştırma kapsamında görüşülen deneyimli işletmelerin konsept ürün çeşitliliğine maksimum derecede önem verdiği görülmektedir. Öte yandan 
tecrübesiz işletmelerin ikili ilişkilere tecrübeli olan işletmelere göre daha fazla itibar ettikleri de gözlenmiştir. Tecrübeye sahip olmadıkları için görev odaklı incelemelerden ziyade partner odaklı seçimlerin yapılması beklenen bir sonuçtur.

Ölçek açısından yapılan karşılaştırmada ulusal marka seçimi yapan işletme sayısının daha yüksek olduğu saptanmıştır. Her ne kadar önceki çalışmalarda uluslararası franchise veren işletmelere sahip franchiseelerin memnuniyet düzeyi ulusal markaya sahip franchiseelere göre daha yüksek olduğu tespit edilmişse de (Abdullaev, 2011) ikili ilişkiler ve yatırım şartlarının uygunluğu konularına dikkat eden işletmelerin büyük oranda ulusal markaları tercih ettiği görülmektedir. Sonuçlar şaşırtıcı değildir. Güvenin franchise ortağı seçiminde oldukça önemli bir yeri olduğu ve Türkiye'nin kolektif bir kültür anlayışına sahip olduğu düşünüldüğünde ikili ilişkilerin ulusal firma tercihinde daha büyük öneme sahip olması beklenen bir sonuçtur. Ayrıca uluslararası franchise veren işletme sahiplerine ulaşmak ulusal franchise veren işletmeye göre çok daha zorlu olacaktır. Ek olarak uluslararası markaların sahip olduğu nispeten yüksek yatırım şartları girişimcileri ulusal firmalara yöneltmektedir. Pazar araştırmasına daha profesyonel açıdan bakan işletmelerin ise uluslararası işletmeleri tercih ettiği görülmektedir.

Farklı bölgelerin sahip olduğu farklı sosyal etkenler o bölgedeki alışkanlıkların, kuralların ve normların yine o bölgede bulunan firmaları etkileyebileceği ve ekonomik faaliyetleri bu sosyal yapının şekillendireceği savunulmaktadır (Simmie, 2001 aktaran Albayrak ve Erkut, 2010). Bu doğrultuda farklı koşullara sahip iki şehir dikkate alınarak, bu illerde girişimcilik faaliyetine başlayacak olan bireylerin franchisor tercinde farklılaşma olup olmadığı incelenmiştir. Antalya ve Burdur her ne kadar komşu iki şehir olsa da birbirlerinden farklı yapıya sahiplerdir. 2014 yılında Türkiye genelinde 81 ili inceleyen rekabet endeksi araştırmasında Antalya'nın dört, Burdur'un ise 26. Sirada olduğunu saptamıştır. Bu sonuç bu iki şehrin birbirlerinden farklı koşullara sahip olduğunu göstermektedir (Dilek ve Al, 2016). Kalkınma Bakanlığının (2013) illerin sosyo-ekonomik gelişmişlik sıralaması araştırmasında Burdur üçüncü kademe gelişmiş iller grubunda yer alırken Antalya birinci kademe gelişmiş illerden biri olmuştur. Bu farklılığa dayanarak, girişimcilerin ortak seçimlerinde birbirlerinden farklılaşan faktörleri dikkate almaları beklenmiştir. Fakat sonuçlar beklenilenin aksi 
yöndedir. Farklı coğrafi koşullara sahip olan girişimcilerin kriterleri birbirlerinden farklılaşmamıştır.

Girişimcilerin eğitim düzeyi dikkate alındığında ise franchising uygulamasını tercih eden lisans ve üstü mezuniyet derecesi olan girişimci sayısının daha yüksek olduğu saptanmıştır. Bu bulgu literatürle uyum göstermektedir. ABD'de yapılan bir araştırmada fast-food işletmelerinde franchise sistemini tercih eden franchiseelerin çoğunun üniversite mezunu ve \%10'unun da liseyi bitirmiş olduğu, İngiltere'de ise franchiseelerin neredeyse \%50'sinin üniversite eğitimi almış kişilerden oluştuğu gözlenmiştir (Seven, 2007). Aynı şekilde konu ile alakalı yapılan diğer çalışmalarda da eğitim seviyesi yüksektir (Alkan, 2015; Seven, 2007; Kurt ve Korkmazyürek, 2019) ve eğitim seviyesi yüksek olan bireyler deneyimli bireyler gibi konsepti hoş ve ürün çeşitliliği yüksek olan girişimlere yönelmişlerdir.

Franchise ortağını seçtikten sonraki süreçte bireylerin franchising sisteminden memnun olup olmadığı ve yaklaşık bir yıl süre sonra faaliyet durumu sorgulanmıştır. $\mathrm{Bu}$ değişkenler hem franchising sisteminin gelecekteki durumu hakkında bilgi vermesi hem de işletmelerin kriterleriyle birlikte bir karşılaştırma yapma olanağ1 sağlaması açısından önem arz etmektedir. Bulgulara göre franchising sistemini tercih eden girişimcilerin yarısından çoğu (11 işletme) memnuniyetini dile getirmiştir. Ayrıca işletmelerin büyük kısmının (10 işletme) faaliyet olduğu görülmektedir. Bu bulgu franchising sisteminin gelecekte de sürdürülebilir bir uygulama olacağını düşündürtmektedir. Çalışmada memnun olmayan işletmelerin neredeyse hepsinin ikili ilişkileri dikkate aldığı saptanmıştır. Öte yandan faaliyetini devam ettirebilen işletmelerin ikili ilişkilere nispeten önem verdiği görülmektedir. Bu durum karmaşık bir görünüm sergilemektedir. İkili ilişkilerin temelinde güven ve iyi niyet bulunmaktadır. Güven ve iyi niyetin de iş birliği hangi durumda olursa olsun dengeleyici ve destekleyici bir rolü bulunmaktadır (Halis, Şenkal ve Türkay, 2009). Öte yandan ikili ilişkiler sübjektif bir değerlendirmeye dayanmakta olup içerisinde risk bulundurmaktadır. Çalışmadaki düşük memnuniyet seviyesi güven duygusuyla birlikte ortaya çıkabilecek algılama hatalarının (örn. Doğrulama yanılgısı, hale etkisi vb.) veya bireylerin sahip olduğu ruh haline, farklı dişsal etmenlere göre gün içerisinde dahi sürekli değişebilen tutumların bir sonucu olduğu düşünülmektedir. 
İşletmelerin günümüzdeki durumu dikkate alındığında ise güvenin, iyi niyetin, ikili ilişkilerin başarı üzerinde pozitif bir etkiye sahip olduğuna inanılmaktadır. İşletmelerin sürdürülebilirliğinde markalaşmanın kısmen etkili olduğu bulgusu ise tüketiciler için öneminin anlaşılması ve tüketicilerde marka bağlılığına, marka sadakatine neden olması nedeniyle şaşırtıcı olmamıştır. Yatırım şartlarının uygunluğu kriterini dikkate alan işletmelerin hepsinin memnun olmadığı bulgusunun saptanması ise pazarda fiyatın oluşmasında tüketicilerin, burada kastedilen franchiseelerin, tatmin durumunun etkisi düşünüldüğünde beklenen bir sonuçtur. Büyüme ise her zaman risk unsurudur. Büyüme hırsı ile girişimlerine başlayan işletmelerin faaliyetlerine son verme olasılığı ise yüksektir.

Franchiseelerin franchise veren işletme seçimi yapmalarının ardından yapılacak anlaşma sırasında zorluk yaşayıp yaşamadıkları incelenmiş ve girişimcilerin sırasıyla finansman, franchisee kimliği, sözleşmenin tek taraflı olması, yer seçimi ve franchisee olarak faaliyete başlama süresinin uzun olması gibi problemlerle karşılaştıkları tespit edilmiştir. Brookes ve Altinay (2011) çalışmasında müzakerelerin başlamasının ardından franchising işletmesinin özelliklerinden ziyade ortakla alakalı kriterlerin baskın olduğu ifade edilmiştir. Bu kriterler arasında ortakların birbirine uyumluluğu, tarafların risk ve değer tanımları, vizyonları, örgüt kültürleri ve hedefleri arasındaki benzerliklerin yer aldığını dile getirilmiştir. Bu süreçte ortakların birbiriyle uyumlu olması kritik bir rol oynayarak görüşmelerin olumlu sonuçlanmasına neden olabilirken (Brookes ve Altinay, 2011) uyumun olmaması da araştırma bulgularında tespit edildiği gibi franchisee kimliğinden dolayı problemlerin yaşanmasına sebebiyet verebilecektir. Bu noktada ise girişimcilerin franchisor seçiminde dikkat ettiği ikili ilişkiler konusunun rol oynayacağı ve görüşme esnasında ikili ilişkileri dikkate alan işletmelerin sorun yaşamayacağ 1 düşünülmüştür. Öte yandan sonuçlar aksini göstermiştir. Literatürde franchising sisteminin dezavantajları arasında yüksek yatırım maliyetlerinin ve oldukça katı ve uzun franchise sözleşmelerinin yer alması (Alkan, 2015) katılımcıların dile getirdiği finansman ve sözleşmenin tek taraflı olması zorluklarının literatürle uyumlu olduğunu göstermektedir. Araştırmada ortaya çıkan, franchise alan girişimcinin franchisee kimliği, yer seçimi ve franchisee olarak faaliyete başlama süresinin uzun olması gibi problemlerin nedeni olarak ise yeterli pazar 
araştırmasının yapılmaması olduğu düşünülmektedir. Girişimcinin, franchise tercihinde bulunulurken işletmenin amaçlarını, misyon ve vizyon ifadelerini ve stratejilerini inceleyip kendi amaçlarıyla yapacağı bir karşılaştırma, franchisee kimliği problemini ve yer seçimiyle alakalı franchisorla uyum problemini çözerken franchise veren işletmenin diğer ortaklarıyla yapacağı görüşmeler ise faaliyete geçme süresi hakkında bilgi sağlamasına imkân verecektir. Araştırmada sorun yaşamadığını bildiren tek işletmenin seçim kriterinin sadece konsept-ürün çeşitliliği olduğu görülmüştür. Diğer birçok işletmenin de aynı kriteri dikkate aldığı ve birçok problemle karşı karşıya kaldığının saptanması bu verinin anlamlı olmadığını göstermektedir. Dolayısıyla gerekli kriterlerin incelenmediği düşünülmektedir. Literatür de bu düşünceyi desteklemektedir. Franchise veren işletmenin finansal güvenilirliği ve geçmişi, franchising uygulamasındaki tecrübesi, pilot operasyon sonuçlarıyla ilgili detaylı bilgi, birlikte çalıştığı franchisee sayısı, franchiseelerle iletişime geçilmesi hakkındaki bakış açısı, kazançlarının ana kaynağı, ürün/hizmetin ücreti - değeri - süresi, franchise veren işletmenin sağlayacağı desteğin türü ve derecesi, verilecek eğitimler hakkında bilgi, verilen eğitimlerin varsa maliyeti, franchise uygulamasının toplam maliyeti, gereken yatırım sermayesi, banka ve diğer referans izinleri, bölgesel uygulama ve bölge koruma, reklam desteğinin türü miktarı, franchisordan mal alımına dair uygulama, hedef konusundaki yaptırımları, karı/zararı, yönetim konusundaki hizmetleri, isim hakkı ödemeleri, operasyon kısıtlamaları, başlangıç yardımı ve sözleşme örneği konularında bilgi alınması franchiseelere önerilmektedir (Seven, 2007). Görüşme yapılan girişimcilerin hemen hemen hiçbirinin literatürde yer alan bu kriterleri dikkate almadığı görülmektedir.

Araştırma kapsamında ayrıca, işletmelerin franchising uygulamasına başlamalarının ardından en fazla yaşanan problemin yanıltıcı/yetersiz danışmanlık olduğu tespit edilmiştir. Bu problem franchisee için kritiktir. Çünkü franchisor tarafından partnere sürekli destek verilmemesi franchising sistemini başarısızlığa uğratan ve sık yapılan hatalardan birini oluşturmaktadır (Seven, 2007). Bir diğer problem olan sözleşme şartlarına hâkim olamamaktan kaynaklanan zorluklar ise girişimcilerin tecrübesizliklerinin veya hukuki bir destek almamalarının bir sonucudur. Girişimciler, franchising sözleşmesindeki maddelerin franchisor lehine 
olduğunu, bazı maddelerin kendi aleyhlerine olduğunu fark edememekte ve sözleşme imzalamadan önce avukatlara danışmamakta ya da yardım aldıysa da yararlı görmemektedirler (Abdullaev, 2011). Yetersiz araştırma franchise görüşmeleri sırasında olduğu gibi sonrasında da zorluklara neden olabilmektedir. Girişimcilerin yaşadığı tedarik zorlukları ve franchise veren işletmenin yeterli tecrübesinin olmamasından kaynaklı zorlukların sebebini oluşturduğu düşünülmektedir. Öte yandan görüşmeler sonrasında hiç zorluk yaşamadığını dile getiren dört işletme bulunmaktadır. Bu işletmelerin firma büyüme potansiyelini ve yatırım şartlarının uygunluğu konularını hiç dikkate almadığı görülmüştür.

Sonuç olarak işletmelerin başarılarını büyük oranda etkileyecek franchisor seçimi sürecinde daha titiz davranmaları, araştırmalarını yoğunlaştırmaları, gerekirse hukuki açıdan destek almaları önerilmektedir. Ayrıca sonraki çalışmalarda katılımcıların belirli zaman aralıklarıyla faaliyet durumlarının incelenmesiyle çalışmanın boyutsal hale getirilmesi veya konunun franchisor gözünden irdelenmesi konuya derinlik katacaktır. Ayrıca bu araştırmanın önemli kısıtı coğrafi olarak birbirine yakın sadece iki ilde yürütülmüş olmasıdır. Bundan sonra yapılacak araştırmalarda farklı bölge ve illerin de araştırma kapsamına dâhil edilmesi önerilmektedir. 


\section{KAYNAKÇA}

Abdullaev, B. (2011). Franchising uygulamalarinda franchise alanlarin memnuniyetine yönelik bir araştırma. (Yayımlanmış yüksek lisans tezi). İstanbul Üniversitesi Sosyal Bilimler Enstitüsü.

Albayrak, A. N. ve Erkut, G. (2010). Türkiye'de il ve bölgelerin rekabet gücü analizi. İTÜ Dergisi/9(2).

Alkan, P. (2015). Türkiye gıda sektöründe franchising uygulamaları. (Yayımlanmış yüksek lisans tezi). Uludağ Üniversitesi Fen Bilimler Enstitüsü.

Alon, I. (2006). Executive insight: evaluating the market size for service franchising in emerging markets. International Journal of Emerging Markets, 1(1), 9-20.

Altinay, L., Brookes M., Madanoglu M. ve Aktas G. (2014). Franchisees' trust in and satisfaction with franchise partnerships. Journal of Business Research, 67, 722-728.

Altinay, L., Brookes, M. ve Aktas, G. (2013). Selecting franchise partners: Tourism franchisee approaches, processes and criteria. Tourism Management, 37, 176-185.

Arman, M., Ekşili, N., Kıran, F. ve Çetinkaya Bozkurt, Ö. (2019). Franchising as a strategic alliance model: a qualitative research. The European Proceedings of Social \& Behavioural Sciences. 324-335.

Aslanoğlu, S. (2007). Bir büyüme stratejisi olarak franchising sistemi; firmalar açisindan önemi, mevzuat boyutu ve muhasebe uygulamasi. Afyon Kocatepe Üniversitesi İktisadi ve İdari Bilimler Fakültesi Dergisi, 9(1), 71-94.

Aşık, N. A. (2017). Değiş̧en kahve tüketim alışkanlıkları ve Türk kahvesi üzerine bir araştırma. Journal of Tourism and Gastronomy Studies, 5(4), 310-325.

Brookes, M. ve Altinay, L. (2011). Franchise partner selection: perspectives of franchisors and franchisees. Journal of Services Marketing, 25(5), 336 - 348.

Brookes, M., ve Roper, A. (2012). Realising plural-form benefits in international hotel chains. Tourism Management. 33(3), 580-591.

Cho, M. (2004). Factors contributing to middle market franchising in Korea: the franchisee perspective. Tourism Management, 25(5), 547-557.

Clarkin, J., ve Rosa, P. (2005). Entrepreneurial teams within franchise firms. International Small Business Journal, 23(3), 303-334.

Clarkin, J. E. ve Swavely S. M. (2006). The importance of personal characteristics in franchisee selection. Journal of Retailing and Consumer Services, 13, 133-142.

Çakal, M. (2012). Stratejik işbirliklerinde partner seçim kriterleri ve stratejik motivasyonlarla performans ilişkisi: türkiye'de kimya sektöründe faaliyet gösteren firmalar üzerine bir araştirma, (Yayımlanmış yüksek lisans tezi). Marmara Üniversitesi Sosyal Bilimler Enstitüsü, İstanbul.

Dilek, P. Y. ve Al, N. (2016). Türkiye İçin Bir Rekabet Endeksi. İmak Ofset Basım Yayın Tic. ve San. Ltd. Şti, 68.

Doherty, A. M. (2009). Market and partner selection processes in international retail franchising. Journal of Business Research, 62(5), 528-534. 
Doherty, A. M. ve Alexander, N. (2004). Relationship development in international retail franchisin: Case study evidence from the UK fashion sector. European Journal of Marketing, 38 (Nos 9/10), 1215-35.

Felstead, A. (1993), The Corporate Paradox Power and Control in the Business Franchise. London: Routledge.

Fladmoe-Lindquist, K. (2000). International franchising: a network approach to FDI. In Y. Aharoni, \& L. Nachum (Eds.), Globalisation of services some implications for theory and practice. London: Routledge.

Franchise Direct. (2020, Şubat 11). Top 100 Franchises 2020. Erişim adresi https://www.franchisedirect.com/top100globalfranchises/rankings

Geringer, J. (1991). Strategic determinants of partner selection criteria in international joint ventures. Journal of International Business Studies, 22 (1), 41-61.

Guilloux, V., Gauzente, C., Kalika, M., ve Dubost, N. (2004). How France's potential franchisees reach their decisions: a comparison with franchisers' perceptions. Journal of Small Business Management, $42(2), 218-224$

Halis, M., Şenkal, A., ve Türkay, O. (2009). Türk İşletmelerinde Ortaklık ve Güven. Journal of Azerbaijan Studies. (10)3, 712-721.

Hitt, A. M., Dacin, T. M., Levitas, E., Arregle, J. ve Borza, A. (2000). Partner selection in emerging and developed market contexts: resource based and organisational learning perspectives. Academy of Management Journal, 43(1), 449-476.

Hitt MA, Ahlstrom D, Dacin MT, Levitas E, Svobodina L. (2004). The institutional effects of strategic partner selection in transition economies: China vs Russia. Organization Science,15 (2):173-85.

Jambulingham, T., Nevin, J.R., (1999). Influence on franchisee selection criteria on outcomes desired by the franchisor. Journal of Business Venturing 14, 363-395.

Jauhari, V., Vaishnav, T., Altinay, L. (2009). The franchise partner selection process and implications for India. Worldwide Hospitality and Tourism Themes. 1(1), 52-65.

Kalkınma Bakanlığı. (2013). İllerin ve bölgelerin sosyo-ekonomik gelişmiş̧lik sıralaması araştırması (SEGE-2011). Bölgesel Gelişme ve Yapısal Uyum Genel Müdürlüğü, Ankara.

Koza, M., ve Lewin, A. (2000). Managing partnerships and strategic alliances: Raising the odds of success. European Management Journal, 18(2), 146-151.

Kurt, Z., \& Korkmazyürek, H. (2019). Franchising uygulamasının başarısını etkileyen faktörler: Mersin ilinde bir araştırma. Toros Üniversitesi İ̇SBF Sosyal Bilimler Dergisi, 6(11), 25-50.

Mason, S. D. ve Duquette, H. G. (2008). Exploring the relationship between local hockey franchises and tourism development. Tourism Management, 29(6), 1157-1165.

Minkler, A. (1990). An empirical analysis of a firm's decision to franchise. Economic Letters. 34, 77-82.

Norton, S. (1988). Franchising, brand name capital, and the entrepreneurial capacity problem. Strategic Management Journal, 9, 105-14. 
Seven, S. (2007). Franchising uygulamalarinda franchise alan firmalari motive eden faktörlerin belirlenmesi: gida ve giyim sektöründe bir uygulama (Yayımlanmış yüksek lisans tezi). Dumlupinar Üniversitesi Sosyal Bilimler Enstitüsü, Kütahya.

Shah, R.H. ve Swaminathan, V. (2008). Actors influencing partner selection in strategic alliances: The moderating role of alliance contex, Strategic Management Journal, 29, 471-494.

Shane, S. A. (1996). Why franchise companies expand overseas. Journal of Business Venturing. 11(2). 73 88.

Tutar, H. (2005). İşletme Yönetimi. Ankara: Seçkin Yayıncılık.

Tuunanen, M. ve Hyrsky, K. (2001). Entrepreneurial paradoxes in business format franchising: an empirical survey of Finnish franchisees. International Small Business Journal, 19(4), 47-62.

UFRAD. (t.y.). Franchise. Erişim adresi https://ufrad.org.tr/franchise/1-franchising-nedir Erişim Tarihi : 8.02.2020

Yıldırım, A. ve Şimşek, H. (2016). Sosyal Bilimlerde Nitel Araştırma Yöntemleri. Ankara: Seçkin Yayıncılık. 